\title{
Optimization Methods for the Extraction of Vegetable Oils: A Review
}

\author{
Divine Bup Nde * and Anuanwen Claris Foncha \\ Department of Nutrition, Food and Bio-Resource Technology, College of Technology, University of Bamenda, \\ P.O. Box 39 Bamenda, Cameroon; fclaris@yahoo.com \\ * Correspondence: bupdiv@yahoo.fr; Tel.: +237-675417724
}

Received: 25 December 2019; Accepted: 30 January 2020; Published: 8 February 2020

\begin{abstract}
Most seed oils are edible while some are used generally as raw material for soap production, chocolate, margarine, and recently in biodiesel formulations as potential candidates capable of replacing fossil fuels which are costly and destructive to the environment. Oilseeds are a green and major reservoir which when properly exploited can be used sustainably for the production of chemicals at both the laboratory and industrial scales. Oil extraction is one of the most critical steps in seed oil processing because it determines the quality and quantity of oil extracted. Optimization of the extraction conditions for each extraction method enhances yield and quality meanwhile a carefully chosen optimization process equally has the potential of saving time and heat requirements with an associated consequence on cost reduction of the entire process. In this review, the techniques used to optimize oil extraction from plant materials which can be consulted by stakeholders in the field are brought to focus and the merits and demerits of these methods highlighted. Additionally, different types of optimization techniques used for various processes including modeling and the software employed in the optimization processes are discussed. Finally, the quality of the oil as affected by the methods of extraction and the optimization process used are also presented.
\end{abstract}

Keywords: oilseeds; oil extraction; experimental designs and optimization; polynomial modelling; optimization software

\section{Introduction}

Many plants contain extractible oils that have for centuries been used either as food or in cosmetic formulations [1]. Recently some of these plant bearing oils have caught the attention of researchers as a source of renewable energy especially in bio-diesel fuel production [2,3]. Oil content of oleaginous seeds, nut, kernel, or fruit pulps varies between $3 \%$ and $70 \%$ of the total weight and has similar chemical structures to animal fats [4]. The benefits that accrue from oilseed processing and sales to individual or grouped farmers, companies, and even to national economies cannot be overemphasized because two of its major products oils and meal or cake are both of great commercial value. For example, in developing countries such as Malaysia, Cameroon, and Ivory Coast there are considerable sections of the population that source their livelihoods principally from palm oil processing and sale. Statistics show that global production of vegetable oil has steadily increased from about 90.5 million metric tons in 2000/2001 to 207.5 million metric tons in 2019/2020 and these trends are expected to continue in the future [5]. Major plant oil sources of commercial importance out of the 40 documented ones that contain edible oils include soybean, sunflower, groundnuts, rapeseed, coconut, and oil palm [6]. Other oilseeds of less commercial importance which are however highly cherished because of the important roles they play in one or more of the following processes; soap production, chocolate, margarine, and biodiesel production etc. include castor, safflower, shea, neem, and tung oils etc. Amongst the many unit operations involved in the processing of oils from oilseeds, extraction remains 
one of the most critical steps because it determines the quality and quantity of the oil extracted. Initial oil content is a major factor that determines the choice of grain processing and extraction methods for the various oil seeds [7].

Although extraction methods especially for the more conventional oilseeds are known, there has been a continuous quest by researchers to improve extraction yields. One proper way of improving extraction yields is to optimize the extraction conditions for each type of extraction method and oilseed because optimum yield will vary with these factors. Apart from enhancing yields and quality, a carefully chosen optimization process equally has the potential of saving time and heat requirements with an associated consequence on reducing the cost of the entire oil extraction process. A number of optimization methods for the extraction of useful components from plant material have been documented in the literature $[1,3,6]$. While many researchers have embraced the investigation of nonconventional oils obviously for the multipurpose uses of the oil, there has not been a corresponding effort in documenting published results on oilseeds in the form of reviews that could be available to stake holders for consultation at all times. The few reviews on this subject have lightly discussed the methods of extraction without laying emphasis on types of oilseeds, optimization methods of the extraction processes, modelling, as well as the influence of the extraction and optimization methods on the quality of the extracted oil [8-10]. Consequently, to the best of our knowledge, there is no comprehensive review on the various techniques used for optimizing oil extraction from plant material. This work therefore presents a review on techniques used to optimize oil extraction from plant material which can be consulted by stakeholders in the field. The work summarizes the general methods of oil extraction from oilseeds, followed by the different types of optimizations techniques used for the various extraction processes including modelling and the software used in the optimization process. The last section of the work is centered on the oil quality as affected by the extraction methods and the optimization process used.

\section{Oil Extraction Methods}

The process of separating triglycedrides from oilseeds is referred to as extraction. This is possible through a variety of chemical, biochemical, and mechanical techniques in order to maximize yields while minimizing alterations on the quality of the product [11]. It is the most important part of oil processing and depends on the part that contains the oil, which is the kernel, the seed, or the pulp [12]. The separation of bio-active compounds of interest in different industries such as food and pharmaceutical usually employs the use of large amounts of solvents (water, n-hexane, ethanol, chloroform, methanol, petroleum ether, etc.). Over the last decades researchers have concentrated lots of efforts on the design of efficient and more sustainable methods of extraction which are less detrimental to the environment [1-15]. Extractions have moved from the conventional solvent and mechanical extractions to improved nonconventional techniques such as Supercritical Fluid Extraction (SFE) and extraction assisted by ultrasound (UAE) and microwaves(MAE) [16-18].Grinding is a very essential operation in the preparation of materials for oil extraction irrespective of the method that follows because when carefully controlled it can lead to the achievement of high oil yields and positively influences downstream operations [19].

\subsection{Mechanical Extraction (ME)}

Mechanical extraction is one of the oldest methods used for oil extraction. In principle, the seeds are placed between barriers where the volume available to the seed is reduced by pressing thereby forcing oil out of the seeds [20]. For application in rural areas, mechanical extraction is habitually used because it has a lower initial investment cost and does require highly trained personnel to operate the machines. The quality of oil obtained by this method is most often measured as a factor of its acid value, phosphorus content, water content, and iodine value [3]. Advantages of mechanical extraction include the production of good quality oil and the possibility of the use of its cake compared to when extraction is done in solvents. Oil extraction by mechanical presses is the most common and entails the 
use of either hydraulic presses or screw presses driven by a motor [2,21]. Even though mechanical pressing is efficient, it usually results in very low oil yield [3]. The advantages of the screw press over the hydraulic press are its slightly improved yields and its ability to be adapted for continuous processing. Heriawan et al. [22] studied a screw configuration of four types of screws; transport, forward, reserve, and idle screws and two types of barrel filters for the extraction of oil from Nyamplung Seeds (Calophyllum inophyllum L.) and concluded that it is necessary to configure mechanical extractors per the seed material used because it can greatly impact the yield. Mariano et al. [23] (2017), studied a mechanical screw press powered by a $2.2 \mathrm{~kW}$ electric motor to study the influence of temperature $\left(50\right.$ and $\left.70{ }^{\circ} \mathrm{C}\right)$, rotational screw speed $\left(22\right.$ and $32 \mathrm{rpm}$ ), and seed pretreatment (seeds heated at $50{ }^{\circ} \mathrm{C}$ in an oven compared to unheated ones) on tobacco oil yield. An optimum oil yield of $73.38 \% \pm 0.307 \%$ $(w / w)$ was obtained with heat treated samples at $70{ }^{\circ} \mathrm{C}$ and $32 \mathrm{rpm}$. In addition to temperature, Gikuru and Lamech [24], also studied the effect of compression pressure and duration of applied force on the extraction yield of soybean oil using the traditional optimization method of keeping some factors constant while varying one at a time. The results showed an increase in the process parameters leads to an increased yield but there exist an optimum bulk temperature which should not be exceeded in order to maximize oil yield. The study also showed that there is a linear relationship between oil yield and both the magnitude of expressing force and the duration of its application.

\subsection{Conventional Solvent Extraction (CSE)}

The conventional solvent extraction (CSE) process is amongst other factors based on the ability of the solvent to dissolve oils and to extract them from the seeds. Therefore, the solvent must be able to solubilize the oil for an efficient extraction. It is the most commonly used method usually carried out either as a batch or continuous process. The three major steps involved in solvent extraction are oilseed cleaning and conditioning, oil extraction, and separation of the miscella. Crude oil and meal quality depend mostly on type of solvent used, reaction temperature, and type of pretreatment given to the oilseed $[25,26]$. The solvent-extraction method is preferable because it is cost efficient and easy to use [18]. Bhuiya et al. [2] studied the oil extraction process from beauty leaf seed of Australian origin and observed that the solvent extraction process was more reproducible, with relative ease of seed preparation and did not require extensive training compared to the mechanical extraction method. Jahiru et al. [27] compared the use of screw press mechanical and solvent extraction methods of oil from beauty leaf and also concluded that the solvent method was superior to the mechanical. The method however requires an extra refining step or process to obtain oil of required quality [28]. CSE has a 90\%-98\% oil recovery rate but requires high energy, high investments, and the solvent most often used (hexane) is hazardous and can cause health problems with prolonged exposure [29-31]. Balaji et al. [26] reported that ethanol is more effective in the extraction of oil from Tamarindus indica compared to n-hexane, petroleum ether, chloroform, methanol, chloroform, methanol (2:1v/v), and iso-propanol and recommended the use of ethanol; a safe and green solvent, in place of other solvents. Guilherme et al. [32] using subcritical propane obtained more yield as opposed to pressurized ethanol under similar conditions. Despite the shortcomings of hexane as an oil extraction solvent it is still being used in research and in some oil process plants. For example, Haitham et al. [33] reported higher oil extracting yields from sesame seeds with n-hexane (37.03\%) compared to chloroform $(6.73 \%)$ and acetone $(4.37 \%)$. Temperature increases diffusivity and solubility of oil which consequently improves the extraction rate [34].

\subsubsection{Enzyme Assisted Extraction (EAE)}

Plant cell walls are made up of lignocellulosic, and other polymers intertwined with each other, which provide a barrier to extraction of its components [35]. Enzymes are used for the digestion of these cellular materials and disruption of pores as a pre-extraction step which eases the diffusion of the oil into the extraction medium [36,37]. Some of the most effective enzymes used are from the fungus Trichoderma [38]. The choice of enzyme used depends on the structure of oilseed, enzyme 
composition, type of enzyme, experimental conditions, etc. Cellulases, hemicellulases, and pectinases, are commonly used during EAE to hydrolyze and degrade the cell wall thus improving the release of intracellular content [39,40]. EAE are used by oil industries because they are site specific and operate at low temperatures [30]. Farah et al. [41] studied the effect of different enzymes (cellulose, amylase, and cellulose+amylase) at different temperatures $\left(35,50\right.$, and $\left.65^{\circ} \mathrm{C}\right)$ and extraction times $(8,16$, and $24 \mathrm{~h})$ on the yield of onion oil. The best yield of $18.38 \%$ was obtained from samples extracted using a combination of amylase and cellulose at $65^{\circ} \mathrm{C}$ for $16 \mathrm{~h}$. Mai et al. [42] also support the idea that a combination of enzymes leads to a better extraction. Even though the use of single enzymes (protease, cellulose, pectinase, and $\alpha$-amylase) led to a significant increase in the quantity of oil extracted from gac (Momordica cochinchinensis Spreng.) fruits compared to the control; a combination of all four enzymes in equal proportions gave a higher yield compared to when the enzymes were used singly. Ferreira et al. [43] reported similar trends when they used four different commercial enzymes separately and in combination, in the extraction of oils from the pulp of Euterpeoleracea fruit. Despite some of these recorded successes with enzyme extractions, it is worth noting that Anwar et al. [44] reported a lower yield for enzyme extraction (35.2\%-38.0\%) compared to the conventional soxhlet extraction $(42.6 \%)$ in a study with viscozyme, feedzyme, and kemzyme assisted cold press extraction of oil from flaxseeds. This lower yield was attributed to the low extraction temperatures probably because the most suitable temperature range for most enzymes used for oil extraction is $40-55^{\circ} \mathrm{C}$ [45]. Sharma et al. [46] reported a significant effect of temperature on extraction yields of peanut oils at $40{ }^{\circ} \mathrm{C}$ which however dropped significantly when temperatures were reduced to $37^{\circ} \mathrm{C}$. The drop was associated with a possibility of enzyme thermo-inactivation. Danso-Boateng [47] also reported maximum oil extraction yields from sunflower kernel when treated with a combination of steam explosion and viscozyme compared to CSE. Lower seed material to water ratios can lead to reduced oil yields because the mixture will be too viscous and difficult to homogenize and an excessive amount of water in the mixture would inevitably lower the concentration and the hydrolysis efficacy of the enzyme [48]. Shah et al. [49] reported a suitable 1:1 solid to liquid ratio during the extraction of oils from Jatropha curcas L. seed kernels; reducing the volume of t-butanol by half reduces the oil yield whereas doubling the volume did not have any significant effect on the quantity of oil extracted. In order to assess the effect of $\mathrm{pH}$ on EAE of oil from Pistacia khinjuk using protease and $\alpha$-amylase, Ahmadi and Karimi [30] performed extractions in the $\mathrm{pH}$ range $4-9$ by adding desired amounts of $\mathrm{HCl}$ $0.1 \mathrm{~N}$ or $\mathrm{NaOH} 0.1 \mathrm{~N}$ into the slurry. The results indicated that the oil recovery from the seeds using $\alpha$-amylase in an aqueous medium increased with an increase in $\mathrm{pH}$ while using protease enzyme, there was an initial increase in oil recovery with an increase in $\mathrm{pH}$ which decreased slightly afterwards. In the production of shea butter from shea nuts the $\mathrm{pH}$ range of 4-6 was found suitable in the presence of crude Pectinase and commercial Pectinex but at very low or higher $\mathrm{pH}$ values, the produced oil had high viscosity making separation by centrifugation very difficult, which was reflected in the low quantity of oil recovered [50].

\subsubsection{Ultrasound Assisted Extraction (UAE)}

Ultrasound is a special type of sound wave beyond human hearing, with frequencies ranging from 20 to $100 \mathrm{MHz}$ [51]. Advantages of UAE include shorter extraction times, low energy demands, and high extraction efficiency [16,52]. UAE is mainly attributed to the behavior of cavitation which brings about the formation and growth of bubbles and its subsequent collapse. The result of this collapse are physico-chemical and mechanical effects which provoke disruption of material matrix, facilitating release of extractable compounds and aiding the movement of the solvent into the sample thus increasing the release of target compounds from matrix into the solvent [53]. Even with the advent of some other novel techniques of extraction such as microwaves, UAE is preferred by some researchers because among other factors it is highly efficient and saves time [54]. Wang and Wei [55] demonstrated that an increase in ultrasonic power led to an increase in oil yield that, however, dropped significantly when ultrasonic power exceeded $90 \mathrm{~W}$ (optimal ultrasonic power). It was explained that the oscillation 
rate of the solvent and oil increased at higher ultrasonic power thereby facilitating the dissolution of seed oil. At ultrasonic powers greater than $90 \mathrm{~W}$, the cavitation produced by the ultrasonic waves does not only disrupt the cell wall, but also damages the molecular structure of the seed oil, leading to a decrease in extraction rate. In an ultrasonic comparative assessment of biodiesel production from rapeseed, Ibiari et al. [56] showed that using ultrasound assisted soxhlet extraction reduces extraction time by about $62 \%$, but the percent recovery was slightly lower than that of the conventional soxhlet extraction. This low recovery rate was attributed to the high frequency $(800 \mathrm{KHz})$ ultrasound employed. Extraction time also affects yield as demonstrated by Lin et al. [57] who obtained an optimum yield of $86.5 \%$ for hempseed oil extraction after $30 \mathrm{~min}$. There was a significant increase in oil extraction yield as extraction time increased from 15 to $30 \mathrm{~min}$ but after $30 \mathrm{~min}$ there was a significant drop in the oil due probably to destruction of the cell material as earlier explained. Rosas-Mendoza et al. [58] reported a $10 \%$ increase in yield for UAE during extraction of chia seed oil compared to $69.2 \%$ for soxhlet extraction. Moreover, the researchers reported gains in extraction time because optimum yield was achieved at $60 \mathrm{~min}$ for UAE while the same yield was obtained at $90 \mathrm{~min}$ for solvent extraction. Isopencu et al. [59] optimized ultrasonic intensity (UI), temperature, and time in the extraction of sea buckthorn oil. For optimized extraction, operation conditions were $13.77 \mathrm{~W} / \mathrm{cm}^{2} \mathrm{UI}, 40^{\circ} \mathrm{C}$, and $10 \mathrm{~min}$ extraction time for UAE. These results were compared to MAE parameters of microwave power, time, and solid/liquid-ratio variables. The $225 \mathrm{~W}$ microwave power, $15 \mathrm{~mL} / \mathrm{g}$ solid/liquid ratio, and $20 \mathrm{~min}$ extraction time were the optimum conditions necessary to obtain a yield of $87.4 \% \pm 0.44 \%$. The results showed that maximum yields for UAE were obtained in half the time required for microwave assisted extraction (MAE). Yousuf et al. [60] demonstrated that in the UAE of soybean oil, increase in power, sonication time, and solvent volume all had an increasing significant effect on oil yield. These studies corroborate that of Wang and Wei [55], that assert that increasing sonication time disrupts the cell wall and increases the interaction region between the solvent and the material thereby increasing the amount of oil extracted. As the ultrasonic power increases, the temperature and pressure within the bubbles of the solvent cause the breakdown of these bubbles; this violent shock boosts the permeation of the solvent into the cell tissues and speeds up the intracellular product discharge into the solvent. Additionally, with increasing solvent volume there is an increase in the concentration difference of the oil in the seed material and the solvent which aids mass transfer.

\subsubsection{Microwave Assisted Extraction}

Microwave assisted extraction (MAE) is one of the most recent and attractive alternative oil extraction methods [61]. The protein material is denatured during microwave treatment leading to an improved extraction [62]. The rapid heating and destruction of biological cell structure by the microwave ensures effective extraction within a short time requiring small amounts of solvent and produces high quality oil [63-65]. Another important advantage of this process is the lower energy requirement which decreases environmental impact and financial costs [58]. The mechanism of MAE is attributed to ionic conduction and dipole rotation resulting from the effect of the microwaves on the molecules of the material undergoing processing. Ionic conduction caused by the electrophoretic migration and the dipole rotation of realignment of ions under an applied electromagnetic field results in an increase in temperature of the extraction medium $[28,66]$. MAE is greatly influenced by the solubility of the compounds of interest in the solvent, partition coefficient, mass diffusivity, and the dielectric properties of the feedstock and the solvent [59]. Mgudu et al. [66] investigated the effect of the microwave treatment on the yield and quality of the oil obtained from castor beans and showed that the microwave treatment gave optimum yields of $44.34 \%$ at a power of $280 \mathrm{~W}$ after $120 \mathrm{~s}$. Mosquera et al. [67] also reported that a better quality palm oil with a lower unsaturated fatty acid content even though a lower yield was obtained from the MAE process compared to expeller press and solid-liquid extraction. Taghvaei et al. [68] reported a MAE yield of $32.6 \%$ compared to $34.7 \%$ obtained from the soxhlet extraction after $3.5 \mathrm{~min}$ and $16 \mathrm{~h}$ extraction time, respectively. Even though MAE has been proven to extract several valuable phytochemicals, the thermal character of the method makes it 
unsuitable for the extraction of polyunsaturated fatty acids (PUFAs) due to their high vulnerability to oxidation and degradation [60]. Nde Bup et al. [69] also used MAE for the extraction of sheanut butter, where they reported substantial gains in extraction time and reduction in the quantity of solvent used compared to CSE. They reported an optimum yield of $31.6 \%$ after heating for $23 \mathrm{~min}$ at $75^{\circ} \mathrm{C}$ and with a solvent/solute ratio $4: 1$ as opposed to $10 \mathrm{~h}, 65^{\circ} \mathrm{C}$, and a solvent/solute ratio of 10:1 for solvent extraction

\subsection{Supercritical Fluid Extraction (SFE)}

SFE separates components from the matrix with the use of supercritical fluids. This method is sometimes referred to as the supercritical carbon extraction method [70]. Solvents used in this method include compressed gases such as ethane, propane, ethylene, dinitrogenoxide, and carbon dioxide [71]. Carbon dioxide with properties of 10-50 MPa pressures and $35-80^{\circ} \mathrm{C}$ temperatures [72] is the most frequent solvent used because it has a relatively low critical temperature $\left(31.1^{\circ} \mathrm{C}\right)$, is nontoxic, nonflammable, with good solvent power, low viscosity, high diffusivity, can be easily removed from the product (does not leave organic solvent residues), and is readily available at low cost [73-75]. SFE involves heating the solvent to above its critical point and at a pressure above $1100 \mathrm{psi}$. The rate at which this it is pumped through the sample is between 10 and 40 volumes [76]. SSFE is sometimes preferred because it avoids the coextraction of impurities (heavy metals and organic derivatives) in preference to the extraction of low polar lipid compounds [77]. Together with the supercritical carbon dioxide $\left(\mathrm{SC}-\mathrm{CO}_{2}\right)$ other solvents usually referred to as cosolvents (e.g., methanol, ethanol, isopropanol, and acetone) can also be used in SFE. These cosolvents come most often to boost the poor polarity of SC- $-\mathrm{CO}_{2}$ and to increase its ability to solvate the analyte of interest [78]. The carbon dioxide used can be recycled, thereby reducing energy consumption and increasing the overall sustainability [79]. Unlike other methods such as CSE, UAE, and MAE that require thermal treatment after extraction, the separation of supercritical carbon dioxide from the extracted oil occurs by simple depressurization [80]. Bhupesh et al. [81] showed that in the extraction oil from sunflower seeds, yield increased with the increasing temperatures at $40 \mathrm{MPa}$ and decreased with increasing of temperatures at $20 \mathrm{MPa}$. They also noted that the effect of pressure was highest at temperatures of $70^{\circ} \mathrm{C}$ and lowest at $40^{\circ} \mathrm{C}$ and suggested the use of higher temperatures and lower pressures. At higher temperatures and their corresponding pressures, the plant tissues are softened thereby increasing the solubility of the oils which leads to increased yields [70]. Sarmento et al. [82] evaluated the effect of process temperature and pressure for the SFE of rice bran oil, enriched with tocopherols and/or tocotrienols. The ranges of temperature and pressure studied were $25-60^{\circ} \mathrm{C}$ and $150-250$ bar, respectively. Reduction in the density of the solvent was thought to be at the origin of an increased in process yield increased with decreasing process temperature at constant pressure. Diofanor et al. [83] also studied the effects of temperature and pressure on the SFE process of oils from grape seeds and showed that higher yields $(10.5 \%)$ were obtained at lower temperatures $(313 \mathrm{~K})$ and attributed the observation to the high solvent power of SC- $-\mathrm{CO}_{2}$ because it has a higher density at the lower temperature. Using three $\mathrm{CO}_{2}$ flow rates (1-5 g/min), operating at $30 \mathrm{MPa}, 40{ }^{\circ} \mathrm{C}$, and a particle size of $0.40 \mathrm{~mm}$, it was established that higher flow rates lead to higher oil extraction yield $(9.8 \%$ and $10.5 \%$ at 1 and $5 \mathrm{~g} / \mathrm{min}$, respectively). In addition, oil yield increased with a reduction in particle size (10.5\%and $9.4 \%$ at 0.80 and $0.40 \mathrm{~mm}$, respectively) at $30 \mathrm{MPa}, 313 \mathrm{~K}$, and $5 \mathrm{~g} / \mathrm{min}$. Hu et al. (2013) reported maximum extraction at 60-80 mesh size in combination with temperature $\left(30^{\circ} \mathrm{C}\right)$, pressure $(343.5 \mathrm{MPa})$, and $\mathrm{CO}_{2}$ flux $(80 \mathrm{~mL})$ for oil extraction from Cuminum cyminum seeds. During extraction of oils from two tucuma species (Amazon tucumã (AT) and Parátucumã (PT) fruits) it was observed that sometimes the material is not very accessible to the supercritical solvent thereby lowering yield [84].

From the preceding analysis, it is observed that recent research on vegetable oil extractions has been focused more on the assisted methods (microwave and ultrasound) and supercritical fluid extraction compared to the conventional solvent and mechanical extraction methods. Oil extraction efficiency and oil quality is a function of the oil bearing material and the extraction method used. 


\section{Methods of Optimization for Vegetable Oil Extraction}

Most optimization methods entail the application of statistical software to optimize the control variables (extraction time, sample weight, solvent volume, nature of solvent, seeds' variability, and particle size, etc.) that seek reduce cost and increase performance while at the same time minimizing deterioration of the quality of the product as much as possible $[18,85]$. With respect to oil extraction, two main methods of process optimization can be identified in the literature: the traditional or conventional optimization method in which a single variable is changed at a time instead of all simultaneously, sometimes referred to as single parameter optimization and that in which a number of variables can be varied simultaneously to take care of interactions that can occur between the factors known as design of experiments (DOE) [86].

\subsection{Single Parameter Optimization}

To determine the best conditions for oil extraction some researchers have taken the approach of changing a single factor at a time while other factors are kept constant [87]. In this case the ideal level for one factor which provides the best response is defined. This process is not only laborious but erroneous as it does not consider interactions because the optimum level of a factor is determined based on certain levels of other factors. These optimum levels could change if different values of the constant factors are considered [87]. The ability of this method to estimate interaction between factors is limited by the demand of more experimental runs without changing its precision. Due to these limitations of the one parameter optimization, this review is based principally on optimization methods that allow the evaluation of the interaction effect of process variables on response factors being studied.

\subsection{Design of Experiments for Oil Extraction from Plant Seeds}

\subsubsection{Response Surface Methodology (RSM)}

Response Surface Methodology (RSM) uses a number of mathematical and statistical techniques which are employed to model and analyze problems in two or more process variables that have an influence on the intended response $[4,16,85,88,89]$ and the objective is to identify the optimal operating conditions for a system under study [90,91]. RSM is based on relating product properties to regression equations that describe inter-relations between input parameters and product properties [26,92]. A major step in optimization is screening the factors studied in order to have the significant effects of the analytical method [93]. RSM reduces the number of experimental runs but maintains the expected accuracy and in addition determines responses for the interactive effect of different variables [94]. The RSM is limited in that data is fitted to a polynomial at the second level but all the systems with curvature might not be compatible with a second-order polynomial model [87]. Amongst the many RSM designs available, the central composite design (CCD) and the Box-Behnken design (BBD) have been popularly used for oil extraction processes.

\section{Central Composite Design (CCD)}

CCD is one of the most commonly used designs in oil extraction processes. Olaoye and Busari [95] stated that this method is preferred when fitting a quadratic surface and it helps to optimize the factors with reduced experimental runs while taking care of interaction between factors. Ogunleye et al. [96] used a CCD with three independent variables (extraction temperature, compression force, and mass of seed) at five levels to perform a total of 20 experiments including eight factorial, six axial, and six center points to optimize mechanical extraction of castor oil from its seeds. The ranges of the parameters studied were $40-200{ }^{\circ} \mathrm{C}, 550-750 \mathrm{kN}$, and 20-100 g for extraction temperature, compression force, and mass of seed, respectively, while the response measured was the oil yield (\%). Optimum reaction conditions were $45^{\circ} \mathrm{C}$ reaction temperature, $745.38 \mathrm{kN}$ force, and mass of $99.88 \mathrm{~g}$ which gave an optimum crude oil yield of $31.01 \%$. Hui et al. [97] used a CCD with two variables each at five levels to 
optimize the UAE extraction of raspberry seed oil. The effects of process variables, sonication time and extraction temperature on oil recovery and quality (vitamin E content, and antioxidant capacity), were investigated. The fitted models gave significant $p$-values of $0.0007,0.0035$, and 0.0022 for extraction yield, vitamin E content, and antioxidant capacity, respectively, with corresponding $\mathrm{R}^{2}$ values of $0.93,0.89$, and 0.90 . In addition, lack of fit for all the three responses were insignificant with values greater than 0.05. The analysis of results from the microwave assisted extraction yield of sandalwood oil by Kusuma and Mahfud [28] (2016), using CCD with the following independent variables: microwave power (400-800 W), plant material to solvent ratio $\left(0.10-0.20 \mathrm{~g} \mathrm{~mL}^{-1}\right)$, and extraction time (C: $\left.40-120 \mathrm{~min}\right)$ showed that the developed polynomial represented the data very well with the $R^{2}$ and $R^{2}$ adj values of 0.9594 and 0.9229 , respectively. Other forms of CCDs such as Central Composite Rotatable Designs (CCRD) and Faced Centered Composite Design (FCCD) have also been reported in the literature for oil extraction processes.

Central Composite Rotatable Designs (CCRD)

The use of CCRD is also common and widely acceptable for multi-variable optimization [98]. For example, Bamgboye and Adejumo, [99] applied a five factor four level CCRD for the optimization of the mechanical press extraction of oil from roselle oilseeds. The factors studied were applied pressure, moisture content ( $\%$ dry basis), heating temperature, heating time, and pressing time for both fine and coarse samples. The $\mathrm{R}^{2}$ and standard error (SE) values obtained for the fine and coarse samples used in the study were 0.98 and $1.53 \%$ and 0.97 and $1.64 \%$, respectively, which indicated a good fit for the experimental data. Olaoye and Busari [95] optimized the mechanical expression of castor seed oil using CCRD. The effect of reaction temperature, reaction time, and moisture content on oil yield was evaluated and a maximum yield of $26.5 \%$ was obtained at moisture content, heating temperature, and reaction time of $6.68 \%, 100{ }^{\circ} \mathrm{C}$, and $15 \mathrm{~min}$, respectively. The resulting $\mathrm{R}^{2}$ and $\mathrm{R}^{2}$ Adj for the selected model were 0.9883 and 0.9778 , respectively, which demonstrated the suitability of the equation to fit the data obtained. The very low $p$-value of moisture content $(<0.0001)$ showed that it had the most significant effect on the process. Badwaik et al. [100] also used the CCRD to evaluate the suitability of different solvents for the extraction of oil from defatted peanut. Hexane was a preferred solvent compared to acetone, benzene, chloroform, and petroleum ether under the reaction conditions of solvent/solute ratio and extraction time of 1:6 and $5 \mathrm{~h}$, respectively, with an $\mathrm{R}^{2}$ value of 0.900 for the developed model. A three-factor five-level CCRD was used by Jiyane et al. [101] to study Croton gratissimus seeds' oil extraction. The effect of extraction time, extraction temperature, and solvent-to-feed ratio on the oil yield was investigated using $n$-hexane and ethyl acetate as extraction solvents. $R^{2}$ of the models developed were 0.98 and 0.97 for $n$-hexane and ethyl acetate extraction, respectively, which demonstrated that the models developed adequately represented the processes studied.

\section{Faced Centered Composite Design (FCCD)}

Another type of CCD that has also been employed in modeling oil extraction processes is the Faced Centered Composite Design (FCCD). Erna et al. [3] optimized the mechanical oil extraction from Jatropha curcas L. kernel using a FCCD in which the effects of applied pressure, temperature, and moisture content of the oil seed on oil yield were studied. Contrary to Erna et al. [3], who reported a moisture content of 7\% required for optimum oil extraction, Olaoye and Busari [95] reported a lower moisture content of $4 \%$ (w.b). The difference was attributed to the type of seed material used. The $R^{2}$ and $R^{2}$ Adj for oil extraction from Jatropha curcas L. kernel were 0.987 and 0.975 , respectively, which indicated that the estimated model fitted the experimental data satisfactorily. In the SFE of sunflower oil, Amit et al. [102] used a FCCD to obtain $R^{2}, R^{2}$ adj, and predicted $R^{2}$ values of 0.9998 , 0.9989 , and 0.3848 , respectively, for the selected quadratic model. The very low value for predicted $R^{2}$ was explained by the presence of many insignificant values in the model. 


\section{Box-Behnken Design (BBD)}

BBD does not include experimental runs for which the upper and lower limits of the factors are simultaneously measured and therefore is not suitable for experiments performed at extreme conditions [57]. This is however a limitation for experiments where the results for these extreme cases are necessary. Faiznur et al. [16] used the BBD to optimize UAE of oil from Calophyllum inophyllum by studying the effects of extraction time, ultrasound power, extraction temperature, and liquid to solid (L/S) ratio) on the oil yield. The experimental data was fitted to a quadratic model using multiple regression analysis to obtain an $R^{2}$ value of 0.984 . The predicted oil yield was optimum $(56.2 \%)$ when the extraction was conducted for $21 \mathrm{~min}, 210 \mathrm{~W}$ ultrasound power, $42{ }^{\circ} \mathrm{C}$ extraction temperature and $21 \mathrm{~mL} / \mathrm{g} \mathrm{L} / \mathrm{S}$ ratio. These results were very close to the experimental values, meaning that the BBD was successful in optimizing the extraction process. Using the BBD Ogbeide et al. [103] studied the optimization of the extraction process conditions of gmelina seed oil. The interaction effect of process parameters agitation time (10-60 min), volume of solvent $(50-150 \mathrm{~mL})$, and particle size (150-1000 $\mu \mathrm{m})$ on oil yield was evaluated. The optimum conditions of seed particle size of $150 \mu \mathrm{m}$, solvent volume of $150 \mathrm{~mL}$, and agitation time of $60 \mathrm{~min}$ gave an oil yield of $52.09 \%$. The BBD has also been used to optimize UAE processes. For example, Faiznur et al. [16] used the BBD to optimize UAE of oil from Callophyllum inophyllum. Parameters optimized were extraction time, ultrasound power, extraction temperature, and liquid to solid (L/S) ratio to obtain an optimum yield of $56.2 \%$ when the extraction was conducted for $21 \mathrm{~min}$, at $210 \mathrm{~W}$ ultrasound power at $42{ }^{\circ} \mathrm{C}$ with a $21 \mathrm{~mL} / \mathrm{g} \mathrm{L} / \mathrm{S}$ ratio. The selected model had an $\mathrm{R}^{2}$ value of 0.984 . Oniya et al. [30] also used BBD to optimize solvent extraction of oil from sandbox kernel. An optimum oil yield of $63.4 \%$ was defined under optimum conditions of seed/solvent ratio $0.05 \mathrm{~g} / \mathrm{mL}$, extraction temperature $68.13{ }^{\circ} \mathrm{C}$, and extraction time of $5 \mathrm{~h}$.

Some few studies have been dedicated to the comparison of the designs commonly used in optimizing oil extraction from oilseeds. For example, Olivera et al. [104] used the extraction of hempseed oil (HSO) to compare BBD, FCCD, and Full Factorial Designs (FFD) basically to see if the simple BBD and FCCD could replace the more complex and expensive FFD. All tested models were significant with a confidence level of $95 \%$. The $\mathrm{R}^{2}$ for BBD was 0.942 compared to that for FCCD, which was 0.742 , showing that the BBD had the best value. Even though their $\mathrm{R}^{2}$ values differed they all gave the same optimal temperature. FFD models defined a lower solvent-to-seed ratio and a slightly shorter extraction time than the BBD and FCCD-based models. All the models predicted best HSO yields which were close to the experimental yields obtained under the same optimum extraction conditions (about $30 \mathrm{~g} / 100 \mathrm{~g}$ ). In other fields the BBD and Doehlert have also been shown to be better than the CCD, but much more efficient than the traditional FFD [104]. Table 1 summarizes some common plant material whose oil extraction conditions have been studied by RSM. 
Table 1. Response Surface Methodology (RSM) parameters, type of oilseed, and solvent type on oil yield.

\begin{tabular}{|c|c|c|c|c|c|c|c|c|}
\hline Plant Material/Seed Used & & Parameters Studied & Method & Solvent/or Enzyme & RSM & Optimum Conditions & Optimum Yield & References \\
\hline \multirow[t]{2}{*}{ Neem seeds } & \multirow[t]{2}{*}{$\begin{array}{l}\text { Parts of Africa, } \\
\text { Indian subcontinent }\end{array}$} & $\begin{array}{l}\text { Extraction time, solvent volume, } \\
\text { and Neem powder weight }\end{array}$ & Solvent extraction & $n$-hexane & BBD & $\begin{array}{l}\text { Extraction time }=30.00 \mathrm{~min} \text {, seed } \\
\text { variability }=181.896 \mathrm{~mL} \text {, and Neem } \\
\text { powder weight }=30 \mathrm{~g}\end{array}$ & $45.650 \%(w / w)$ & [18] \\
\hline & & $\begin{array}{l}\text { Extraction time, temperature, } \\
\text { solvent/solute ratio }\end{array}$ & MAE & $n$-hexane & Doehlert & $\begin{array}{l}\text { Extraction time } 24 \mathrm{~min} \text {, temperature } \\
80^{\circ} \mathrm{C} \text {, solvent/solute ratio } 3: 1\end{array}$ & $31.68 \%$ & [65] \\
\hline Sheanut kernels & $\begin{array}{l}\text { Central and } \\
\text { West Africa }\end{array}$ & $\begin{array}{l}\text { Extraction time, temperature, } \\
\text { solvent/solute ratio }\end{array}$ & MAE & $n$-hexane & Doehlert & $\begin{array}{l}\text { Extraction time } 24 \mathrm{~min} \text {, temperature } \\
80^{\circ} \mathrm{C} \text {, solvent/solute ratio } 3: 1\end{array}$ & $31.58 \%$ & [69] \\
\hline Jatropha curcas & $\begin{array}{l}\text { Mexico and central } \\
\text { America, lately parts } \\
\text { of Tropical Africa }\end{array}$ & $\begin{array}{l}\text { Type of solvents, temperature, } \\
\text { solvent to solid ratio, processing } \\
\text { time, and particle size of the meal }\end{array}$ & CSE & $\begin{array}{l}\text { Petroleum ether } \\
\text { n-hexane }\end{array}$ & Not applicable & $\begin{array}{l}8 \mathrm{~h} \text { reaction time, temperature of } \\
\text { around } 68^{\circ} \mathrm{C} \text {, coarseparticle size } \\
(0.5-0.75 \mathrm{~mm}) \text {, solvent to solid ratio of } \\
6: 1 \text {, and hexane as solvent }\end{array}$ & & [105] \\
\hline Thevetia peruviana & $\begin{array}{l}\text { Tropical America and } \\
\text { Tropical Africa }\end{array}$ & $\begin{array}{l}\text { Polarity, extraction time, } \\
\text { and extraction temperature }\end{array}$ & CSE & $\begin{array}{l}\text { Petroleum ether } \\
\text { Methanol }\end{array}$ & Not applicable & $\begin{array}{l}\text { Extraction time } 4.5 \mathrm{~h} \text {, extraction } \\
\text { temperature } 65^{\circ} \mathrm{C} \text {, petroleum ether to } \\
\text { methanol ratio } 90: 10 \text { (polarity } \\
\text { index 0.6) }\end{array}$ & $51.88 \% \pm 3.18 \%$ & [106] \\
\hline Rice bran & $\begin{array}{l}\text { Mainly Japan, } \\
\text { Thailand, India, } \\
\text { China, and Vietnam }\end{array}$ & $\begin{array}{l}\text { Temperature, stirring rate, } \\
\text { solvent-bran ratio, and contact time }\end{array}$ & CSE & Acetone, ethanol & $\mathrm{CCD}$ & $\begin{array}{l}\text { Temperature } 55^{\circ} \mathrm{C} \text {, solvent-bran ratio } \\
\text { 6:1, stirring rate } 180 \mathrm{rpm} \text {, and contact } \\
\text { time } 45 \mathrm{~min}\end{array}$ & $82 \%$ & [107] \\
\hline Ocimum basilicum L. & $\begin{array}{l}\text { India, Africa, } \\
\text { and South East Asia }\end{array}$ & $\begin{array}{l}\text { Raw material size, raw material to } \\
\text { water ratio, extraction time, } \\
\text { and microwave power }\end{array}$ & MAE & Water & $\mathrm{CCD}$ & $\begin{array}{l}\text { Water-to-material ratio of } 3.2: 1, \\
\text { extraction time of } 97 \mathrm{~min}, \\
\text { and microwave power of } 430 \mathrm{~W}\end{array}$ & $0.6 \%$ & [108] \\
\hline Gourd seeds & \multirow{2}{*}{$\begin{array}{l}\text { Canada, Argentina, } \\
\text { South and Central } \\
\text { America }\end{array}$} & $\begin{array}{l}\text { Roasting temperature } \\
\left(87.70-172.0^{\circ} \mathrm{C}\right) \text { and roasting } \\
\text { duration }(7.93-22.07 \mathrm{~min}) \\
\end{array}$ & $\mathrm{ME}$ & Not applicable & CCRD & $\begin{array}{l}\text { Roasting temperature } 100^{\circ} \mathrm{C} \text {, } \\
\text { roasting time } 20 \mathrm{~min}\end{array}$ & $27.62 \%$ & [109] \\
\hline $\begin{array}{l}\text { Elateriospermumtapos } \\
\text { seed }\end{array}$ & & $\begin{array}{l}\text { Microwave power }(110-1100 \mathrm{~W}) \text {, } \\
\text { extraction time }(30-120 \mathrm{~s}), \text { enzyme } \\
\text { cocktail concentration }(1 \%-5 \%), \\
\text { and particle size }(0.5-1.5 \mathrm{~mm})\end{array}$ & MAE & $\begin{array}{l}\text { Cellulase pectinase } \\
\text { proteinase }\end{array}$ & $\mathrm{CCD}$ & $\begin{array}{l}110 \mathrm{~W} \text { microwave power, } 30 \mathrm{~s} \\
\text { extraction time, } 1 \% \text { cocktail enzyme, } \\
\text { and } 0.5 \mathrm{~mm} \text { particle size. }\end{array}$ & $46.12 \% \pm 1.48 \%$ & [39] \\
\hline $\begin{array}{l}\text { Momordicacochin chinensis } \\
\text { (Gac fruit) }\end{array}$ & $\begin{array}{l}\text { South China, } \\
\text { Thailande, Laos, } \\
\text { Myanmar, Cambodia, } \\
\text { Vietnam, North East } \\
\text { Australia }\end{array}$ & $\begin{array}{l}\text { Enzyme ratio/\% (5-25), reaction } \\
\text { time/min }(60-180) \text {, reaction } \\
\text { temperature/ } /{ }^{\circ} \mathrm{C}(40-80) \text {, stirring } \\
\text { speed/rpm }(50-250)\end{array}$ & EAE & $\begin{array}{l}\text { Pectinase, protease, } \\
\text { a-amylase and } \\
\text { cellulose }\end{array}$ & $\mathrm{CCD}$ & $\begin{array}{l}\text { Enzyme mass per volume ratio of } \\
14.6 \% \text {, incubation time of } 127 \text { min, } \\
\text { temperature of } 58^{\circ} \mathrm{C} \text {, and stirring } \\
\text { speed of } 162 \mathrm{rpm}\end{array}$ & $79.5 \%$ & [110] \\
\hline Jatropha seed & & $\begin{array}{l}\text { Solvent to seeds ratio, reaction time, } \\
\text { and reaction temperature }\end{array}$ & CSE & $n$-hexane & BBD & $\begin{array}{l}\text { Solvent to seeds ratio } 14: 1 \text {, reaction } \\
\text { time } 4.4 \mathrm{~h} \text {, and reaction } \\
\text { temperature } 35^{\circ} \mathrm{C} \text {. }\end{array}$ & $51 \%$ & [111] \\
\hline Mauritia Flexuosa & $\begin{array}{l}\text { Amazon forest of } \\
\text { Brazil and Peru, } \\
\text { South America }\end{array}$ & $\begin{array}{l}\text { Temperature, enzyme concentration, } \\
\text { extraction time }\end{array}$ & EAE & $\begin{array}{l}\text { Water, cellulase, } \\
\text { pectinase, } \\
\text { and protease }\end{array}$ & CCRD & $\begin{array}{l}\text { Temperature } 55^{\circ} \mathrm{C}, 2 \% \text { enzyme } \\
\text { concentration, and } 6 \mathrm{~h} \text { extraction time }\end{array}$ & $76.5 \%$ & [112] \\
\hline Citrus sinensis & Tropics & Roasting time, roasting temperature & CSE & NA & CCRD & $\begin{array}{l}\text { Roasting temperature } 170^{\circ} \mathrm{C} \text {, roasting } \\
\text { time } 30 \mathrm{~min}\end{array}$ & $56 \% \pm 6.5 \%$ & [91] \\
\hline
\end{tabular}


Table 1. Cont.

\begin{tabular}{|c|c|c|c|c|c|c|c|c|}
\hline Plant Material/Seed Used & & Parameters Studied & Method & Solvent/or Enzyme & RSM & Optimum Conditions & Optimum Yield & References \\
\hline Croton gratissimus & $\begin{array}{l}\text { Tropical and } \\
\text { Sub-Tropical Africa }\end{array}$ & $\begin{array}{l}\text { Seed to solvent ratio, extraction time, } \\
\text { extraction temperature }\end{array}$ & CSE & $\begin{array}{l}\text { ethyl acetate } \\
n \text {-hexane, }\end{array}$ & CCRD & $\begin{array}{l}\text { Seed to solvent ratio } 5 \mathrm{~mL} / \mathrm{g} \text {, extraction } \\
\text { temperature: } 35^{\circ} \mathrm{C} \text { (both solvents) } \\
\text { extraction time6 min with } n \text {-hexane, } \\
20 \text { min with ethyl acetate }\end{array}$ & $9.21 \%$ & [101] \\
\hline Calophylluminophyllum & $\begin{array}{l}\text { Tropical and some } \\
\text { temperate regions }\end{array}$ & $\begin{array}{l}\text { Extraction time, ultrasound power, } \\
\text { extraction temperature, and liquid to } \\
\text { solid (L/S) ratio }\end{array}$ & UAE & $n$-hexane & BBD & $\begin{array}{l}\text { Extraction time } 21 \mathrm{~min} \text {, ultrasound } \\
\text { power } 210 \mathrm{~W} \text {, extraction temperature } \\
42{ }^{\circ} \mathrm{C} \text {, and } \mathrm{L} / \mathrm{S} \text { ratio } 21 \mathrm{~mL} / \mathrm{g}\end{array}$ & $56.2 \%$ & [16] \\
\hline Pomegranate seed & $\begin{array}{l}\text { Middle East, } \\
\text { Caucasus region, } \\
\text { North and } \\
\text { TropicalAfrica, the } \\
\text { Indian subcontinent, } \\
\text { Central Asia }\end{array}$ & $\begin{array}{l}\text { Power (176-300 W), time }(5-20 \mathrm{~min}) \\
\text { particle size }(d=0.125-0.800 \mathrm{~mm}), \\
\text { and solvent to sample ratio }(2: 1,6: 1, \\
\text { and 10:1, by mass) }\end{array}$ & MAE & $n$-hexane & FCCD & $\begin{array}{l}\text { Microwave power of } 220 \mathrm{~W} \text {, particle } \\
\text { size in the range of } d=0.125-0.450 \mathrm{~mm} \text {, } \\
\text { and solvent-to-sample ratio of } 10: 1 \\
\text { (by mass) in } 5 \text { min extraction time }\end{array}$ & $35.19 \%$ & [61] \\
\hline $\begin{array}{l}\text { Pomegranate } \\
\text { (Punicagranatum L.) peel }\end{array}$ & & $\begin{array}{l}\text { Pressure, temperature, extraction } \\
\text { time, and modifier (methanol) } \\
\text { volume }\end{array}$ & SFE & Methanol & CCD & $\begin{array}{l}350 \text { atm pressure, } 55^{\circ} \mathrm{C} \text { temperature, } \\
30 \text { min extraction time, and } 150 \mu \mathrm{L} \\
\text { methanol }\end{array}$ & & [73] \\
\hline Raspberry seed oil & Temperate zones & $\begin{array}{l}\text { Sonication time and extraction } \\
\text { temperature }\end{array}$ & UAE & Not mentioned & $\mathrm{CCD}$ & $\begin{array}{l}\text { Sonication time of } 37 \mathrm{~min} \text { and } \\
\text { extraction temperature of } 54^{\circ} \mathrm{C}\end{array}$ & $23 \%$ & [98] \\
\hline
\end{tabular}




\section{Modeling and Validation of Models}

In RSM, the phenomenon being studied is usually represented by Equation (1)

$$
Y=f\left(U_{i j}\right)
$$

$Y$ is the dependent variable of interest to be measured usually referred to as the response. $U_{i j}$ are the independent variables that can influence a particular response normally called factors. $f$ is a mathematical function which predicts the different responses depending on the values of $U_{i j}$. A second order polynomial with interaction (Equation (2)) is widely used to model the responses $[18,71,101,102]$.

$$
Y=b_{0}+\sum_{j=1}^{k} b_{j} x_{j}+\sum_{j-1}^{k} b_{j j} x_{j}^{2}+\sum \sum_{i<j} b_{i j} x_{i j}
$$

where $b_{0}, b_{i}, b_{j j}$, and $b_{i j}$ are regression coefficients for intercept, linear, quadratic, and interaction terms, respectively, and $x_{i}$ and $x_{j}$ are coded independent variables. Many extraction processes used the regression coefficient $\mathrm{R}^{2}$ and/or absolute/standard error of deviation (SED) for the validation of the models used. A model is considered good if $\mathrm{R}^{2}>0.70$ and/or SED $<10 \%$ [113].

\section{Types of Software Used}

The use of response surface methodology in food science has increased in recent years [36,42,62]. During optimization a second order polynomial is developed to model the responses and data obtained from optimization is sometimes subjected to simple ANOVA, $t$-test [36], and/or to some free or commercial statistical packages (Table 2). Design Experts (Stat-Ease, Inc., Minneapolis, MN, USA) was used to optimize the microwave extraction of pomegranate seed oil, mechanical extraction of gourd seed oil [58,108], Sigma plot version 12.5for CSE of oil from neem seed [66]. Paramita et al. [114] used MATLAB Version 5.0 to analyze data from the supercritical carbon extraction of cotton seed oil. IBM SPSS was the statistical package chosen by Krunoslav et al. [115] (201) in their work on the supercritical carbon extraction of hemp seed oil. Minitab version 15.5 is also commonly used [116]. 
Table 2. Summary of model validation parameters and type of modelling software use.

\begin{tabular}{|c|c|c|c|c|c|c|c|c|c|c|c|}
\hline Plant Species & DOE Used & $\begin{array}{l}\text { Parameter (s) } \\
\text { Analyzed }\end{array}$ & DP Used & $\begin{array}{l}\text { Model } \\
\text { Validation } \\
\text { Criteria Used }\end{array}$ & Value of $R^{2}$ SED etc. & & $\begin{array}{l}\text { Quality } \\
\text { Parameters }\end{array}$ & $\begin{array}{l}\text { Quality } \\
\text { Value }\end{array}$ & Validity & Software Used & References \\
\hline Neem seeds & Doehlert & $\begin{array}{l}\text { Oil yield } \\
\text { Acid value }\end{array}$ & 2 & $R^{2}$ and SED & $\begin{array}{l}\mathrm{R}^{2} \\
\text { Oil yield: } 0.862 \\
\text { Acid value: } 0.884\end{array}$ & $\begin{array}{l}\text { SED } \\
\text { Oil yield: } 2.45 \% \\
\text { Acid value: } 5.40 \%\end{array}$ & Acid value & $\begin{array}{l}4.02 \mathrm{mg} \text { of } \\
\mathrm{KOH} / \mathrm{g} \text { oil }\end{array}$ & $\begin{array}{l}\text { Valid } \\
\text { Valid }\end{array}$ & Sigmaplot 12 & [65] \\
\hline Ofada rice brand & $\begin{array}{l}\text { RSM (Specific } \\
\text { type not } \\
\text { mentioned) }\end{array}$ & $\begin{array}{l}\text { Yield, free fatty acid, } \\
\text { color, and peroxide } \\
\text { value }\end{array}$ & 2 & $R^{2}$ & $\begin{array}{l}\text { Yield: } 0.79, \\
\text { Fatty acids: } 0.91, \\
\text { Color: } 0.99 \text {, and } \\
\text { Peroxide value: } 0.99\end{array}$ & & $\begin{array}{l}\text { Moisture content } \\
\text { Acid value } \\
\text { Refractive Index }\end{array}$ & $\begin{array}{l}43.00 \% \pm \\
1.41 \% \text { w.b } \\
8.13 \% \pm \\
0.78 \% \\
1.461 \pm 0.01\end{array}$ & Valid & $\begin{array}{l}\text { Design } \\
\text { Expert Version } \\
8.0 .1 .0 \\
\text { (StateaseIn; } \\
\text { Minneapolis } \\
\text { USA, version). }\end{array}$ & [117] \\
\hline Neem seeds & $\begin{array}{l}\text { Box-Behnken } \\
\text { design }\end{array}$ & Yield & 2 & $R^{2}$ & Yield: 97.55\% & & $\begin{array}{l}\text { Iodine value } \\
\text { Saponification } \\
\text { value } \\
\text { FFA } \\
\text { Acid value }\end{array}$ & $\begin{array}{l}112.31 \mathrm{mg} \\
\text { of } \mathrm{I}_{2} / 100 \mathrm{~g} \\
198 \mathrm{mg} \text { of } \\
\mathrm{KOH} / \mathrm{g} \\
1.91 \% \\
3.82 \mathrm{mg} \text { of } \\
\mathrm{KOH} / \mathrm{g}\end{array}$ & Valid & $\begin{array}{l}\text { Design Expert } \\
\text { 9.0.3.1 }\end{array}$ & [18] \\
\hline $\begin{array}{l}\text { PistaciaKhinjuk } \\
\text { Seeds }\end{array}$ & $\begin{array}{l}\text { Central } \\
\text { composite } \\
\text { design }\end{array}$ & Yield & 2 & $R^{2}$ & Yield: 0.99 & & & & Valid & $\begin{array}{l}\text { "Design } \\
\text { expert" } \\
\text { (version 5) and } \\
\text { "Statistica" } \\
\text { (version 5) } \\
\end{array}$ & [30] \\
\hline Orange seeds & $\begin{array}{l}\text { Central } \\
\text { Rotatable Design }\end{array}$ & $\begin{array}{l}\text { Yield } \\
\text { FFA } \\
\text { Refractive index } \\
\text { Color } \\
\text { pH } \\
\text { Specific gravity }\end{array}$ & 2 & $R^{2}$ and $p$-Values & $\begin{array}{l}R^{2} \\
\text { Yield: } 0.83 \\
\text { FFA: } 0.67 \\
\text { Refractive index: } 0.80 \\
\text { Color: } 0.91 \\
\text { pH: } 0.77 \\
\text { Specific gravity: } 0.91\end{array}$ & $\begin{array}{l}p \text {-Value } \\
\text { Yield: } 0.014 \\
\text { FFA: } 0.001 \\
\text { Refractive index: } 0.24 \\
\text { Color: } 0.002 \\
\text { pH: } 0.3 \\
\text { Specific gravity: } 0.001\end{array}$ & $\begin{array}{l}\text { FFA } \\
\text { Color } \\
\text { Specific gravity } \\
\text { pH }\end{array}$ & $\begin{array}{l}1.4 \% \\
4.7 \text { abs } \\
0.92 \\
5.4\end{array}$ & All valid & $\begin{array}{l}\text { Design Expert } \\
\text { Version } 6.0 .10 \\
\text { (Stat Ease } \\
\text { Minneapolis, } \\
\text { USA) }\end{array}$ & [4] \\
\hline Peanut & $\begin{array}{l}\text { Central } \\
\text { Rotatable Design }\end{array}$ & $\begin{array}{l}\text { Oil recovery } \\
\text { Surface appearance } \\
\text { Sensory color } \\
\text { Overall acceptability }\end{array}$ & 2 & $R^{2}$ and F-Values & $\begin{array}{l}R^{2} \\
\text { Oil recovery: } 0.900 \\
\text { Surface } \\
\text { appearance: } 0.822 \\
\text { Sensory color: } 0.800 \\
\text { Overall acceptability: } 0.845\end{array}$ & $\begin{array}{l}\text { F-Value } \\
\text { Oil recovery: } 32.59 \\
\text { Surface appearance: } 6.48 \\
\text { Sensory color: } 4.60 \\
\text { Overall acceptability: } 7.38\end{array}$ & l & I & All valid & $\begin{array}{l}\text { "Design } \\
\text { expert" } \\
\text { (version 5) }\end{array}$ & [100] \\
\hline
\end{tabular}


Table 2. Cont

\begin{tabular}{|c|c|c|c|c|c|c|c|c|c|c|}
\hline Plant Species & DOE Used & $\begin{array}{l}\text { Parameter (s) } \\
\text { Analyzed }\end{array}$ & DP Used & $\begin{array}{l}\text { Model } \\
\text { Validation } \\
\text { Criteria Used }\end{array}$ & Value of $R^{2}$ SED etc. & $\begin{array}{l}\text { Quality } \\
\text { Parameters }\end{array}$ & $\begin{array}{l}\text { Quality } \\
\text { Value }\end{array}$ & Validity & Software Used & References \\
\hline Calophylluminophyllum & $\begin{array}{l}\text { Box-Benkhen } \\
\text { Design }\end{array}$ & Yield & 2 & $R^{2}$ & Yield: 0.984 & -1 & I & Valid & $\begin{array}{l}\text { Design Expert } \\
\text { (Version 6.0.6, } \\
\text { Stat- } \\
\text { Ease Inc., } \\
\text { Minneapolis, } \\
\text { Minnesota, } \\
\text { USA). }\end{array}$ & [16] \\
\hline $\begin{array}{l}\text { Cannabis sativa } \mathrm{L} \text {. } \\
\text { seed }\end{array}$ & & $\begin{array}{l}\text { Concentration of } \\
\text { tocopherols, fatty } \\
\text { acids, and pigments }\end{array}$ & 2 & $R^{2}$ & $\begin{array}{l}\text { Concentration of tocopherols } \\
\text { Fatty acids } \\
\text { Pigments }\end{array}$ & $\begin{array}{l}\text { Acid value } \\
\text { FFA } \\
\text { Iodine value } \\
\text { Saponification } \\
\text { value } \\
\text { Cetane number }\end{array}$ & $\begin{array}{l}1.8048 \mathrm{mg} \\
\mathrm{KOH} / \mathrm{g} \text { oil } \\
0.9024 \% \\
97.60 \mathrm{~g} \\
\mathrm{I} 2 / 100 \mathrm{~g} \text { oil } \\
57.5025 \mathrm{mg} \\
\mathrm{KOH} / \mathrm{g} \text { oil1 } \\
40.998\end{array}$ & Valid & IBM SPSS & [115] \\
\hline
\end{tabular}

$\mathrm{DP}=$ Degree of polynomial, $\mathrm{DOE}=$ Design of experiment 


\section{Quality of Oil}

In most studies, even though the quantity of oil obtained is the most studied response, some researchers have also studied the effect of various parameters on the quality of the extracted oil. Free fatty acid, saponification value, refractive index, moisture content, and color are some of the responses that have been studied. The variables studied and the methods used have an effect on the quality of the oil obtained. Following mechanical extraction and optimization of oils from gourd seeds, Yetunde et al. [109] reported saponification value, refractive index, specific gravity, FFA, and color of $289.66 \mathrm{~mL}, 1.47,0.90 \mathrm{~g} / \mathrm{mL}, 0.61 \%$, and 3.47 abs, respectively. Nde Bup et al. [118] reported optimum ranges of 5-20 min cooking time and $40-50{ }^{\circ} \mathrm{C}$ cooking temperature for the extraction of neem oil and indicated that the parameters analyzed (moisture content, refractive index, quantity of oil, and acid value) were significantly affected by the independent factors. Optimum responses obtained at the mid points of the optimum ranges for moisture content, oil content, acid value, and refractive index were $46.37 \%$ w.b., $21.43 \%, 3.53 \mathrm{mg} \mathrm{KOH} / \mathrm{g}$ oil, and 1.460, respectively. Under optimum processing conditions of $19 \mathrm{MPa}$ applied pressure, $90{ }^{\circ} \mathrm{C}$ pressing temperature, and $3.8 \%$ (w.b.) moisture content, Erna et al. [3] obtained oil that met the DIN 51605:2010-10 standard for fuels made from plant oils except for its phosphorus content and group II metals. Dang and Nguyen [119] studied the effect of cold-pressing, solvent extraction, and enzyme assisted aqueous extraction on the quality of oil extracted from cashew nuts. These methods were compared for oil quality indicators, such as specific gravity, free fatty acid (FFA), peroxide values (PV), total phenolic (TPC), total flavonoid content (TFC), fatty acid composition, and storage stability. Solvent extraction gave higher yields but oil from cold-pressing was most stable against oxidization and rancidity and could be kept fresh for 12 months, while the enzyme and solvent extraction oils lasted 8 months without major changes, at room temperature. The work of Gutte et al. [53] on the ultrasonic extraction and fatty acid profile showed $11.5 \%$ improvement of extraction yield at the optimum conditions of frequency of $40 \mathrm{kHz}$, temperature of $30^{\circ} \mathrm{C}$, extraction time of $40 \mathrm{~min}$, and solid to solvent ratio: 1:10. They also reported an improved extraction of all fatty acids and a significant increase in polyunsaturated fatty acids. Uitterhaegen et al. [120] reported that the screw configuration and pressing temperature optimized in the screw press method of extraction had no significant effect on the quality of the oil obtained. Pomegranate seed oil extracted by MAE showed a significantly lower peroxide value $\left(0 \mathrm{mmol}\right.$ of $\mathrm{O}_{2}$ per $\mathrm{kg}$ of oil), free fatty acidity $(0.42 \%)$, and higher total phenolic $(7.42 \mathrm{mg} / \mathrm{g})$ and antioxidant activity $\left(5 \mathrm{mg} / \mathrm{mL}\right.$ ) compared to the cold extraction which gave $4 \mathrm{mmol}$ of $\mathrm{O}_{2}$ per $\mathrm{kg}$ peroxide value, $1.73 \mathrm{mg} / \mathrm{g}$ phenolic content, and an antioxidant activity of $17.00 \mathrm{mg} / \mathrm{mL}$ [61]. The difference in antioxidant activity was attributed to differences in total phenolic content.

\section{Conclusions}

Oil extraction methods from oil seeds include conventional methods (solvent and mechanical extraction) and nonconventional or improved techniques (supercritical fluid extraction, ultrasound, microwave, and enzyme assisted extraction. These nonconventional techniques are innovative and have potential to improve oil extraction rates, shorten extraction times, and minimize deterioration of the oil quality. The nonconventional methods have been used successfully to reduce some of the loopholes of the conventional methods of oil extraction. Response surface methodology is the most commonly used method to optimize oil extraction from plant material. Box-Behnken and Doehlert are better than the Centre Composite Design but much more efficient than the traditional full factorial design. Design expert, Sigma Plot version 12.5, MATLAB version 5.0, IBM SPSS, and Minitab version 15.5 have been commonly used to optimize the extraction of oil seeds. The variables studied and the methods of extraction used have an effect on the quality of oil obtained. Some of the quality parameters studied were saponification value, refractive index, specific gravity, moisture content, FFA, and color. The majority of studies carried out on the nonconventional methods of oil extraction have been centered on laboratory batch processes. There is need to extend the research to continuous microwave and ultrasound assisted extraction as well as supercritical fluid extraction systems at the 
laboratory scale and subsequent scale-up to both pilot and industrial systems. An important and useful extension of this work is to carry out the economic evaluation of the various nonconventional extraction systems to evaluate their profitability.

Author Contributions: D.B.N. conceived the topic and structure as well as corrected the manuscript. A.C.F. wrote the first draft of the manuscript. All authors have read and agreed to the published version of the manuscript.

Funding: This research received no external funding.

Conflicts of Interest: The authors declare no conflict of interest.

\section{References}

1. Yusuf, A.K. A Review of Methods Used for Seed Oil Extraction. IJSR 2018, 7, 233-238.

2. Bhuiya, M.M.K.; Rasul, M.G.; Khan, M.M.K.; Ashwath, N.; Azad, A.K.; Mofijur, M. Optimisation of Oil Extraction Process from Australian Native Beauty Leaf Seed (Calophyllum inophyllum). Energy Procedia 2015, 75, 56-61. [CrossRef]

3. Erna, S.; Robert, M.; Hero, J.H.; Antonius, A.B. Optimization of mechanical oil extraction from Jatropha curcas L. kernel using response surface method. Ind. Crop Prod. 2015, 63, 294-302.

4. Akinoso, R.; Aboaba, S.A.; Olajide, W.O. Optimization of roasting temperature and time during oil extraction from orange (citrus sinensis) seeds: A response surface methodology approach. Afr. J. Food Agric. Nutr. Dev. 2011, 11, 5300-5317.

5. Statista. Available online: https://www.statista.com/statistics/263978/global-vegetable-oil-production-since2000-2001 (accessed on 12 December 2019).

6. Sharma, M.; Mondal, A.K.; Gupta, S.K. Production and trade of major world oil crops. In Technological Innovations in Major World Oil Crops; Springer: New York, NY, USA, 2011; pp. 1-15.

7. Santos, R.F.; Fornasari, C.H.; Bassegio, D.; de Souza, S.N.; Secco, D. Optimization of oil extraction from high energetic potential plants performed through drying and solvent extraction methods. Afr. J. Biotechnol. 2013, $12,6761-6765$.

8. Sheikh, A.M.S.; Kazi-Syed, Z. Technologies for oil extraction: A Review. Intl. J. Envt. Agric. Biotechnol. 2016, 1, 106-110.

9. Bhargavi, G.; Nageswara, P.R.; Renganathan, S. Review on the extraction methods of crude oil from all Generation Biofuels in last few decades. IOP Comf. Ser. Mater. Sci. Eng. 2018, 330, 012024. [CrossRef]

10. Akindele, F.A.; Nsuhoridem, I.J. Extraction of vegetable oils from agricultural materials: A Review. In Proceedings of the 12th CIGR Section VI International Symposium, International Institute of Tropical Agriculture, Ibadan, Nigeria, 22-25 October 2018; pp. 1185-1206.

11. Gnansounou, E.; Raman, J.K. Life cycle assessment of algal biorefinery. In Life Cycle Assessment of Biorefineries; Gnansounou, E., Pandey, A., Eds.; Elsevier: Cambridge, UK, 2017; pp. 199-219.

12. Baskar, G.; Kalavathy, G.; Aiswarya, R.; Selvakumari, I.A. Advances in bio-oil extraction from nonedible oil seeds and algal biomass. In Advances in Eco-Fuels for a Sustainable Environment; Woodhead Publishing Series in Energy: Cambridge, UK, 2019; pp. 187-210.

13. El-Nadi, Y.A. Solvent extraction and its applications on ore processing and recovery of metals: Classical Approach. Sep. Purif. Rev. 2017, 46, 195-215. [CrossRef]

14. Kumar, S.P.J.; Rajendra, S.P.; Rintu, B.; Dinesh, K.A.; Kalyani, S.K.; Ramesh, K.V. Green solvents and technologies for oil extraction from oilseeds. Chem. Central J. 2017, 11, 9. [CrossRef] [PubMed]

15. Deepika, R.S.; Gagandeep, K.S. Response surface methodology to optimize enzyme-assisted aqueous extraction of maize germ oil. J. Food Sci. Technol. 2016, 53, 3282-3295.

16. Faiznur, M.F.; Khairiah, A.K.; Mashitah, M.D. Ultrasonic-assisted extraction of oil from Calophyllum inophllum seeds: Optimization of process parameters. J. Phy. Sci. 2016, 27, 103-121.

17. Bimakr, M.; Ali, G. Supercritical cardon dioxide extraction of bioaction compounds. Food Nutr. J. 2016, 48-56. [CrossRef]

18. Adepoju, T.F.; Olawale, O. Optimization and predictive capability of rsm using controllable variables in Azadiracha indica oilseeds extraction process. Int. J. Chem. Mat. Res. 2015, 3, 1-10. 
19. Arișanu, A.O. Mechanical continuous oil expression from oilseeds: Oil yield and press capacity. In Proceedings of the 5th International Conference "Computational Mechanics and Virtual Engineering", Brasov, Romania, 24-25 October 2013.

20. Elhassan, S.H.A.R. Mechanical Expression of Oil from Sesame (Sesamum indicum L.). Ph.D. Thesis, University of Khartoum, Khartoum, Sudan, 2009.

21. Guédé, S.S.; Soro, Y.R.; Kouamé, A.F.; Brou, K. Optimization of screw press extraction of Citrillus lanatus seed oil and physicochemical characterization. Eur. J. Food Sci. Technol. 2017, 5, 35-46.

22. Heriawan, Y.; Indartono, S.; Ika, A.K. Optimization of mechanical oil extraction process of nyamplung seeds (Calophyllum inophyllum L.) by flexible single screw extruder. AIP Conf. Proc. 2018. [CrossRef]

23. Mariano, C.; Salvatore, F.; Maura, S.; Luca, A. Optimization of hemp seeds (canapa sativa 1.) Oil mechanical extraction. Chem. Eng. Trans. 2017, 58, 373-378.

24. Gikuru, M.; Lamech, M. A Study of Yield Characteristics During Mechanical Oil Extraction of Preheated and Ground Soybeans. J. Appl. Sci. Res. 2007, 3, 1146-1151.

25. Fajriyati, M.; Meta, M.; Amran, L.; Zainal, Z. Optimization of mango seed kernel oil extraction using response surface methodology. OCL 2017, 24, 5.

26. Balaji, P.; Sanjay, D.; Munish, S. Optimization of oil extraction and characterization from tamarindus indica linn seed oil. Int. J. Oil Gas Coal Eng. 2014, 2, 1-6.

27. Jahirul, M.I.; Brown, J.R.; Senadeera, W.; Ashwath, N.; Laing, C.; Leski-Taylor, J.; Rasul, M.G. Optimization of Bio-oil extraction process from Beauty leaf (Calophyllum inophyllum) oil seeds as a second generation biodiesel source. 5th BSME International Conference on Thermal Engennering. Procedia Eng. 2013, 56, 619-624. [CrossRef]

28. Kusuma, H.S.; Mahfud, M. Response surface methodology for optimization studies of microwave-assisted extraction of sandalwood oil. J. Mat. Environ. Sci. 2016, 7, 1958-1971.

29. Oniya, O.O.; Oyelade, J.O.; Ogunkunle, O.; Idowu, D.O. Optimization of solvent extraction of oil from sandbox kernels (Hura crepitans 1.) by a response surface method. Energy Policy Res. 2017, 4, 36-43. [CrossRef]

30. Ahmadi, M.; Karimi, F. Optimization of enzymatic extraction of oil from Pistacia khinjuk seeds by using central composite design. Food Sci. Technol. 2013, 1, 37-43.

31. Evon, P.; Virginie, V.; Pierre, Y.P.; Luc, R. Direct extraction of oil from sunflower seeds by twin-screw extruder according to an aqueous extraction process: Feasibility study and influence of operating conditions. Ind. Crop Product. 2007, 2, 351-359. [CrossRef]

32. Guilherme, S.P.; Thiago, A.W.; Elton Rogério, L.C.; Natalia, P.C.S. Linseed (Linum usitatissimum) oil extraction using different solvents. Food Technol. Biotechnol. 2018, 56, 366-372.

33. Haitham, O.; Ihab, S.; Abubakr, E. Optimization of sesame seeds oil extraction Operating conditions using the response Surface design methodology. Sci. Study Res. Chem. Chem. Eng. Biotechnol. Food Ind. 2016, 17, 335-347.

34. Premi, M.; Sharma, H.K. Oil extraction optimization and kinetics from Moringa oleifera (PKM 1) seeds. Int. J. Agric. Food Sci. Technol. 2013, 4, 371-378.

35. Amudan, R.; Kamat, D.V.; Kamat, S.D. Enzyme-assisted extraction of essential oils from Syzygium aromaticum. South Asian J. Expt. Biol. 2011, 1, 248-254.

36. Wenwei, C.; Huang, G.; Jia, Z.; Hong, Y. Optimization of aqueous enzymatic extraction of oil from shrimp processing by-products using response surface methodology. Food Sci. Technol. AHEAD 2018, 39, 231-236. [CrossRef]

37. Richochon, G.; Muniglia, L. Influence of enzymes on the oil extraction processes in aqueous media. Oléagineux Corps Gras Lipides 2010, 17, 356-359. [CrossRef]

38. Moreau, A.R.; David, B.J.; Michael, J.P.; Kevin, B.H. A comparison of commercial enzymes for the aqueous enzymatic extraction of corn oil from corn germ. JAOCS 2004, 81, 1071-1075. [CrossRef]

39. Nuraimi, T.A.H.; Ida, M.I. Optimization of omega 3 rich oil extraction from elateriospermum tapos seed by microwave assisted aqueous enzymatic extraction. Chem. Eng. Trans. 2017, 56, 1783-1788.

40. Hemavathi, S.; Jamaliah, M.J. Enhancement of palm oil extraction using cell wall degrading enzyme formulation Malaysian. J. Anal. Sci. 2015, 19, 77-87.

41. Farah, S.H.; Rinani, S.A.R.; Masniza, M.; Nor, F.H. Enzyme assisted aqueous extraction and phenolic Antioxidants of onion oil. Int. J. Sci. Environ. Technol. 2013, 2, 949-955. 
42. Mai, C.H.; Vinh, T.; Frederic, D. Optimisation of enzyme-assisted extraction of oil rich in carotenoids from gac fruit (Momordicacochin chinesis spreng). Food Technol. Biotechnol. 2013, 51, 488-499.

43. Ferreira, E.D.S.; Rogez, H.L.G.; Herman, C.A.N.P. Effect of the combination of enzymatic preparations on the aqueous extraction yield of the oil from the pulp of Euterpe oleracae fruit. Braz. J. Chem. Eng. 2018, 35, 1193-1201. [CrossRef]

44. Anwar, F.; Zreen, Z.; Sultana, B.; Jamil, A. Enzyme-aided cold pressing of flaxseed (Linum usitatissimum L.): Enhancement in yield, quality and phenolics of the oil. Grasas Y Aceites 2013, 64, 463-471. [CrossRef]

45. Mat, Y.M.; Gordon, M.; Niranjan, K. Aqueous enzyme assisted oil extraction from oilseeds and emulsion de-emulsifying method. Trends Food Sci. Technol. 2014, 41, 60-82.

46. Sharma, A.; Khare, S.K.; Gupta, M.N. Enzyme-Assisted Aqueous Extraction of Peanut Oil. JAOCS 2002, 79, 215-218. [CrossRef]

47. Danso-Boateng, E. Effect of Enzyme and Heat Pretreatment on Sunflower Oil Recovery Using Aqueous and Hexane Extractions. Int. J. Chem. Biol. Eng. 2011, 4, 1.

48. Qiang, L.; Peiwang, L.; Jingzhen, C.; Changzhu, L.; Lijuan, J.; Mingliang, L.; An, S. Optimization of Aqueous Enzymatic Extraction of Castor (Ricinus communis) Seeds Oil Using Response Surface Methodology. J. Biobased Mat. Bioenergy 2019, 13, 1-9.

49. Shah, S.; Aparna, S.; Gupta, M.N. Extraction of oil from Jatrophacurcas L. seed kernels by enzyme assisted three phase partitioning. Ind. C. Prod. 2004, 20, 275-279. [CrossRef]

50. Otu, S.A.; Dzogbefia, V.P.; Kpikpi, E.N.; Essuman, E.K. Comparative effect of crude and commercial enzyme in shea fat extraction. J. Biotechnol. Biochem. IOSR JBB 2015, 1, 18-27.

51. Selvamuthukumaran, M.; Shi, J. Recent advances in extraction of antioxidants from plant by-products processing industries. Food Qual. Saf. 2017, 1, 61-81. [CrossRef]

52. Senrayan, J.; Venkatachalam, S. A short extraction time of vegetable oil from Carica papaya L. seeds using continuous ultrasound acoustic cavitation: Analysis of fatty acid profile and thermal behavior. J. Food Proc. Eng. 2018, 42, e12950. [CrossRef]

53. Gutte, K.B.; Akshaya, K.S.; Rahul, C.R. Effect of ultrasonic treatment on extraction and fatty acid profile of flaxseed oil. OCL 2015, 22, D606. [CrossRef]

54. Jing, C.; Xiao-fang, D.; Jian-ming, T. Optimization of ultrasonic-assisted extraction of flavonoid compounds and antioxidants from alfalfa using response surface method. Molecules 2015, 20, 15550-15571. [CrossRef]

55. Wang, Y.; Wei, W. Optimization of ultrasound-assisted extraction of Physalis alkekengi L. var. francheti Seed Oil. Chem. Eng. Trans. 2015, 46, 1387-1392.

56. Ibiari, N.N.; El-Enin, S.A.; Attia, N.K.; El-Diwani, G. Ultrasonic comparative assessment for biodiesel production from rapeseed. J. Am. Sci. 2010, 6, 937-943.

57. Lin, J.Y.; Zeng, Q.X.; An, Q.I.; Zeng, Q.Z.; Jian, L.X.; Zhu, Z.W. Ultrasonic extraction of hempseed oil. J. Food Proc. Eng. 2010, 35, 76-90. [CrossRef]

58. Rosas-Mendoza, M.E.; Coria-Hernández, J.; Meléndez-Pérez, R.; Arjona-Román, J.L. Characteristics of chia (salvia hispanica 1.) Seed oil extracted by ultrasound assistance. Mex. Chem. Soc. 2017, 61, 326-335.

59. Isopencu, G.; Marta, S.; Alma, B.; Nicoleta, C.O.; Cristina, P.; Cristina, B.; Anicuta, S.G. Optimization of ultrasound and microwave assisted oil extraction from sea buckthorn seeds by response surface methodology. J. Food Proc. Eng. 2018, 42, 1-12. [CrossRef]

60. Yousuf, O.; Palmei, G.; Anupama, S. Ultrasound assisted extraction of oil from soybean. Int. J. Curr. Microbiol. Appl. Sci. 2018, 7, 843-852. [CrossRef]

61. Hasene, K.Ç.; Derya, K.Y.; Uğur, G.; Fahrett, G. Optimisation of microwave-assisted extraction of pomegranate (Punicagranatum L.) seed oil and evaluation of its hysicochemical and bioactive properties. Food Technol. Biotechnol. 2017, 55, 86-94.

62. Creencia, E.C.; Joshua AP, N.; Ivy, L.L. Microwave-assisted extraction and physicochemical evaluation of oil from Hevea brasiliensis seeds. Resources 2018, 7, 28. [CrossRef]

63. Sun, Y.; Xue, H.K.; Liu, C.H.; Liu, C.; Su, X.L.; Zheng, X.Z. Comparison of microwave assisted extraction with hot reflux extraction in acquirement and degradation of anthocyanin from powdered blueberry. Int. J. Agric. Biol. Eng. 2016, 9, 186-199.

64. Barekati, G.M.; Boldor, D.; Nde Bup , D.B. In-situ transesterification of seeds of invasive Chinese tallow trees (Triadica sebifera L.) in a microwave batch system (GREEN3) using hexane as co-solvent: Biodiesel production and process optimization. Bioresour. Technol. 2016, 201, 97-104. [CrossRef] 
65. Nde Bup , D.; Dorin, B.; Carlos, A. Optimization of microwave assisted extraction parameters of neem (Azadirachta indica A. Juss) oil using the Doehlert's experimental design. Ind. C. Prod. 2015, 65, 233-240.

66. Mgudu, E.M.; Kabuba, J.; Belaid, M. Microwave-assisted extraction of castor oil. In Proceedings of the International Conference on Nanotechnology and Chemical Engineering ICNCS 2012, Bangkok, Thailand, 21-22 December 2012.

67. Mosquera, D.M.; Marcela, P.C.; Rafael, H.G.; Raquel, O.D.; Maria, S.H.; Pablo, J.F.T. Microwave technology applied to natural ingredient extraction from Amazonian fruits. Foods 2013, 1, 1-8.

68. Taghvaei, M.; Seid, M.J.; Elham, A.; Shahram, N.; Omran, A. Optimization of microwave-assisted extraction of cottonseed oil and evaluation of its oxidative stability and physicochemical properties. Food Chem. 2014, 160, 90-97. [CrossRef]

69. Nde Bup , D.; Dorin, B.; Carlos, A.; Pranjali, M.; Zhimin, X. Oil extraction from sheanut (Vitellaria paradoxa Gaertn, C.F.) kernels assisted by microwaves. J. Food Sci. Technol. 2016, 53, 1424-1434.

70. Nuttawan, Y. Optimization of $\mathrm{ScCO}_{2}$ extraction of rambutan seed oil using response surface methodology. Int. J. Chem. Eng. Appl. 2013, 4, 187.

71. Illés, V.; Daood, H.G.; Biacs, P.A.; Gnayfeed, M.H.; Mészáros, B. Supercritical $\mathrm{CO}_{2}$ and subcritical propane extraction of spice red pepper oil with special regard to carotenoid and tocopherol content. J. Chromato. Sci. 1999, 37, 345-352. [CrossRef]

72. Calvo, A.; Morante, J.; PlanderSzSzekely, E. Fractionation of biologically active components of grape seed (vitisvinifera) by supercritical fluid extraction. Actaahmentaria 2017, 46, 27-34.

73. Katayoun, M.A.; Farhad, R. Application of response surface methodology for the optimization of supercritical fluid extraction of essential oil from pomegranate (Punicagranatum L.) peel. J. Food Sci. Technol. 2016, 53, 3113-3121.

74. Hu, L.F.; Jun, H.; Jun-Tao, F.; Xing, Z. Optimization of supercritical $\mathrm{CO}_{2}$ extraction and characterization of antifungal activity of essential oils in 'Cuminum cyminum' L. Aust. J. C. Sci. 2013, 7, 1809-1813.

75. Bravi, M.; Bubbico, R.; Manna, F.; Verdone, N. Process optimisation in sunflower oil extraction by supercritical CO. Chem. Eng. Sci. 2002, 57, 2753-2764. [CrossRef]

76. Sapkale, G.N.; Patil, S.M.; Surwase, U.S.; Bhatbhage, P.K. Supercritical fluid extraction: A review. Int. J. Chem. Sci. 2010, 8, 729-743.

77. Mohammad, M.T.; Bahareh, S.; Mehdi, O. Extraction of oil from tuna by-product by supercritical fluid extraction (SFE) and comparison with wet reduction method. AACL Bioflux. 2017, 10, 1546-1553.

78. Wejnerowska, G.; Ciaciuch, A. Optimization of Oil Extraction from Quinoa Seeds with Supercritical Carbon Dioxide with Co-solvents. Czech J. Food Sci. 2018, 36, 81-87. [CrossRef]

79. Vaibhav, S.; Kakasaheb, M. Supercritical fluid extraction: A new technology to herbals. Int. J. Herb. Med. 2019, 7, 27-34.

80. Duba, K.S.; Fiori, L. Supercritical fluid extraction of vegetable oils: Different approach to modeling the mass transfer kinetics. Chem. Eng. Trans. 2015, 43, 1051-1056.

81. Bhupesh, C.R.; Sasaki, M.; Goto, M. Effect of temperature and pressure on the extraction yield of oil from sunflower seed with supercritical carbondioxide. Int. J. Appl. Sci. 2006, 6, 71-75.

82. Sarmento, C.M.P.; Ferreira, S.R.; Hense, H. Supercritical fluid extraction (sfe) of Rice bran oil to obtain fractions Enriched with tocopherols and Tocotrienols. Braz. J. Chem. Eng. 2006, 23, 243-249. [CrossRef]

83. Diofanor, A.C.; Piedad, M.C.; Raúl, J.M. Effect of the Process Parameters on the Oil Extraction Yield During Supercritical Fluid Extraction from Grape Seed. Contemp. Eng. Sci. 2018, 11, 611-617.

84. Costa, B.E.T.; Orquídea, V.S.; Nádia, C.F.C.; Luiz, F.F. Comparative study on the quality of oil extracted from two tucumã varieties using supercritical carbon dioxide. Food Sci. Technol. Camp. 2006, 36, 322-328. [CrossRef]

85. Yenge Govind, B.; Kanawade, V.L.; Nimbalkar, C.A.; Kenghe, R.N.; Patil, A.P.; More, H.G. Optimization of soxhlet extraction of garden cress oil by response surface methodology. Int. J. Chem. Stud. 2017, 5, 526-530.

86. Masime, J.O.; Ogur, E.; Mbatia, B.; Aluoch, A.O.; Otieno, G. Optimization and Thermodynamics of the Extraction of Yellow Oleander Seed Oil Using Soxhlet Extractor. J. Sci. Achiev. 2017, 2, 43-50.

87. Malina, A.; Marta, S.; Anicuta, S.G.; Octavian, F. Optimization of the Oil Extraction from Camelina (Camelina sativa) Seeds Using Response Surface Methodology. Rev. Chim. Buchar. 2015, 66, 3. 
88. Carley, M.K.; Natalia, Y.K.; Joff, R. Response surface Methodology. Center for Computational Analysis of Social and Organizational Systems (CASOS) Technical Report. 2004. Available online: http://www.researchgate.net (accessed on 25 December 2019).

89. Alev, Y.A. Utilization of Response Surface Methodology in Optimization of Extraction of Plant Materials. InTech 2018, 157-169. [CrossRef]

90. Ovando-Chacón, S.L.; Ovando-Chacón, G.E.; Borraz-Castañeda, D.A. Optimization of the aqueous enzymatic extraction of oil from Oecopetalum mexicanum. Espacio I+D Innovación más Desarrollo 2018, 7, 71-91. [CrossRef]

91. Abd, E.S.; Salah, H.; Nachida, K.M.; Djilali, T.; Tibor, S.; Klára Hand László, N. Using central composite experimental design to optimize the degradation of tylosin from aqueous solution by photo-fenton reaction. Materials 2016, 9, 428.

92. Ferreira, S.C.; Bruns, R.E.; Ferreira, H.S.; Matos, G.D.; David, J.M.; Brandao, G.C.; da Silva, E.P.; Portugal, L.A.; Dos Reis, P.S.; Souza, A.S.; et al. Box-Behnken design: An alternative for the optimization of analytical methods. Anal. Chim. Acta 2007, 597, 179-186. [CrossRef] [PubMed]

93. Adeyanju, J.A.; Grace, O.O.; Adefemiwa, A.A.; Gbemisola, E.A.; Majekolagbe, O.S. Optimization of oil extraction from coconut using response surface Methodology. J. Chem. Pharm. Res. 2016, 8, 374-381.

94. Savic, I.M.; Nikolic, V.D.; Savic-Gajic, I.M.; Nikolic, L.B.; Ibric, S.R.; Gajic, D.G. Optimization of technological procedure for amygdalin isolation from plum seeds (Prunidomesticae semen). Front. Plant Sci. 2015, 6, 276. [CrossRef] [PubMed]

95. Olaoye, J.O.; Busari, R.A. Optimization of mechanical expression of castor seeds oil (Ricinuscommunis) using response surface methodology. Arid Zone J. Eng. Technol. Environ. 2017, 13, 878-887.

96. Ogunleye, O.O.; Babatunde, K.A.; Agbede, O.O. Ricinus cummunis as feedstock for raw vegetable oil expression via mechanical extraction process: Optimization study. LAUTECH J. Eng. Technol. 2016, 10, 74-81.

97. Hui, T.; Chen, L.; Huang, Q.; Wang, J.; Lin, Q.; Liu, M. Ultrasonic-Assisted Extraction of Raspberry Seed Oil and Evaluation of Its Physicochemical Properties, Fatty Acid Compositions and Antioxidant Activities. PLOS ONE 2016, 11, 4.

98. Alhassan, Y.; Kumar, N.; Bugaje, I.M.; Mishra, C. Optimization of Gossypium arboreum seed oil biodiesel production by central composite rotatable model of response surface methodology and evaluation of its fuel properties. J. Pet. Technol. Altern. Fuels 2014, 5, 1-12. [CrossRef]

99. Bamgboye, A.I.; Adejumo, O.I. Optimization of oil extraction from Roselle oilseeds. In Proceedings of the OAU Faculty of Technology Conference, Ile-Ife, Nigeria, 20-25 September 2015; pp. 85-89.

100. Badwaik, L.S.; Prasad, K.; Deka, S.C. Optimization of extraction conditions by response surface methodology for preparing partially defatted peanut. Int. Food Res. J. 2012, 19, 341-346.

101. Jiyane, P.C.; Tumba, K.; Musonge, P. Optimisation of Croton gratissimus Oil Extraction by $n$-Hexane and Ethyl Acetate Using Response Surface Methodology. J. Oleo Sci. 2018, ess17197. [CrossRef] [PubMed]

102. Amit, R.; Bikash, M.; Ravindra, B. Supercritical extraction of sunflower oil: A central composite design for extraction variables. Food Chem. 2016, 192, 647-659.

103. Ogbeide, S.E.; Emmanuel, U.A.; Chinaza, E.N. Optimization of the Extraction Process of Gmelina Seed Oil using Response Surface Methodology. Chem. Res. J. 2018, 3, 94-102.

104. Olivera, S.S.; Milan, D.K.; Dragana, B.R.; Vlada, B.V. Comparison of Box-Behnken, Face Central Composite and Full Factorial Designs in optimization of hempseed oil extraction by $n$-hexane: A case study. Period. Polytech. Chem. Eng. 2018, 62, 359-367.

105. Sepidar, S.; Zurina, Z.A.; Robiah, Y.; Azhari, M. Extraction of Oil from Jatropha Seeds-Optimization and Kinetics. Am. J. Appl. Sci. 2009, 6, 1390-1395.

106. Suwari; Kotta, H.Z.; Buang, Y. Optimization of soxhlet extraction and physicochemical analysis of crop oil from seed kernel of FeunKase (Thevetia peruviana). AIP Conf. Proc. 2017, 1911, 020005.

107. Ahmad, S.W.; Javed, F.; Ahmad, S.; Akram, M.; Rehman, A. Parametric optimization of rice bran oil extraction using response surfacemethodology. Pol. J. Chem. Technol. 2016, 18, 103-109. [CrossRef]

108. Tran, T.H.; Nguyen, H.H.; Nguyen, D.C.; Nguyen, T.Q.; Tan, H.; Nhan, L.T.; Nguyen, D.H.; Tran, L.D.; Do, S.T.; Nguyen, T.D. Optimization of microwave-assisted extraction of essential oil from Vietnamese basil (Ocimum basilicum L.) using response surface methodology. Processes 2018, 6, 206. [CrossRef]

109. Yetunde, Y.P.; Rahman, A.; Akeem, O.R. Optimization of oil extraction from giant bushel gourd seeds using response surface methodology. Food Sci. Nutr. 2016, 4, 759-765. 
110. Huỳnh, C.M.; Debaste, F.V.T. Extraction of Carotenoid-Rich Oil from Gac Fruit. Food Technol. Biotechnol. 2013, 51, 488-499.

111. Lwin, Y.; Khine, M.M. Statistical optimization of oil extraction from Jatrophacurcas seeds using solvent extraction method. In Proceedings of the 3rd International Congress on Interdisciplinary Research and Development, Muang Thong Thani, Bankhok Metro, Thailand, 30-31 May 2013.

112. Silva Jezica, P.P.; Antonio, M.C.R.; Luiza, H.M.S. Aqueous enzymatic extraction of buriti (Mauritiaflexuosa) oil: Yield and antioxidant compounds. Open Food Sci. J. 2019, 11, 9-17. [CrossRef]

113. Nde Bup , D.; Charles, F.A.; Dzulie, T. Optimisation of the cooking process of sheanut kernels (Vitellaria paradoxa gaertn.) using the Doehlert experimental design. Food Bioprocess Technol. 2012, 5, 108-117. [CrossRef]

114. Paramita, B.; Rekha, S.S.; Sudha, R.T. Supercritical carbon dioxide extraction of cottonseed oil. J. Food Eng. 2007, 79, 892-898.

115. Krunoslav, A.; Kristjan, J.; Tina, B.; Senka, V.; Jelena, V.; Mate, B.; Stela, J. Supercritical CO2 extraction of hemp (Cannabis sativa L.) seed oil. Ind. C. Product. 2015, 76, 472-478.

116. Oyekunle, D.T. Optimization of oil extraction from Thevetia peruviana (yellow oleander) seeds: A case study of two statistical models. Int. J. Eng. Modern Technol. 2017, 3, 4.

117. Akinoso, R.; Adeyanju, J.A. Optimization of edible oil extraction from ofada rice bran using response surface methodology. Food Bioprocess Technol. 2012, 5, 1372-1378. [CrossRef]

118. Nde Bup , D.; Siriyabe, M.; Mohagir, M.A.; Fon, A.C.; Zourmba, P.; NkengElambo, G.; Kapseu, C. Evaluation of the cooking process of neem (Azadirachtaindica) nuts as a pretreatment prior to oil extraction. J. Chem. Biol. Phys. Sci. 2014, 4, 3261-3273.

119. Dang, T.Q.; Nguyen, T.K. Impact of extraction method on the oil yield, physicochemical properties, fatty acid composition and stability of cashew nut (anacardium occidentale) oil. EC Nutr. 2019, 14, 165-171.

120. Uitterhaegen, E.; Nguyen, Q.H.; Stevens, C.; Merah, O.; Talou, T.; Rigal, L.; Evon, P. Extraction of coriander oil using twin-screw extrusion: Feasibility study and potential press cake applications. J. Am. Oil Chem. Soc. 2015, 82, 1219-1233. [CrossRef]

(C) 2020 by the authors. Licensee MDPI, Basel, Switzerland. This article is an open access article distributed under the terms and conditions of the Creative Commons Attribution (CC BY) license (http://creativecommons.org/licenses/by/4.0/). 